\title{
ZAKAT SEBAGAI PENGURANG PAJAK DAN PENGARUHNYA TERHADAP PENERIMAAN PAJAK DI SEMENANJUNG MALAYSIA
}

\author{
Eko Suprayitno \\ Dosen Fakultas Ekonomi Universitas Islam Negeri (UIN) Maliki Malang \\ ekonashwan@gmail.com \\ Radiah Abdul Kader \\ Assoc. Prof. Faculty Economics and Administration University of Malaya \\ radiab@um.edu.my \\ Azhar Harun \\ Assoc. Prof. College of Law, Government and International Studies \\ Universiti Utara Malaysia, 06010 UUM Sintok, Kedah Darul Aman \\ b.azhar@uum.edu.my
}

\begin{abstract}
This paper attempts to examine the role of zakat administration policy in Malaysia and its impact on the tax revenue in Malaysia Peninsula. Zakat administration issues pertaining to Islamic law but traditions remain under the jurisdiction of states. The practice of zakat is based on the Shariah while the taxation practice is based on the Malaysian Income Tax Act, established in 1967. Zakat is used as a fiscal policy tool whereby income tax payers were given 100 per cent rebates on zakat that they paid. The study uses panel data of states in Malaysia Peninsula and the analysis is done by using the fixed effect model. The study finds that zakat has a positif impact and significant on tax revenue.
\end{abstract}

Keywords: Zakat Administration, Tax Revenue, Panel Data.

\begin{abstract}
Abstrak
Tulisan ini mencoba untuk mengkaji peran kebijakan administrasi zakat di Malaysia dan dampaknya terhadap penerimaan pajak di Semenanjung Malaysia. Sistem administrasi zakat termasuk bukum Islam dan adat terletak di bawah yurisdiksi setiap Negara Bagian. Kebijakan zakat didasarkan pada Syariab sementara kebijakan perpajakan berdasarkan Undang-Undang Pajak Penghasilan Malaysia, yang dibuat pada tabun 1967. Zakat digunakan sebagai alat kebijakan fiskal dimana penghasilan wajib pajak diberi 100 persen pengurangan terbadap pembayaran
\end{abstract}


pajak dari zakat yang dibayar. Penelitian ini menggunakan data panel dari negara di Semenanjung Malaysia dan analisis dilakukan dengan menggunakan model fixed effect. Hasil analisis mendapati bahwa zakat memiliki dampak positif dan signifikan pada pendapatan pajak. Hipotesis bahwa zakat akan mengurangi penerimaan pajak ditolak.

Kata kunci: Administrasi Zakat, Penerimaan Pajak, Panel Data

\section{Pendahuluan}

Filsafat Islam memprioritaskan tujuan utama kepada kepentingan masyarakat dibandingkan dengan kepentingan pribadi ataupun golongan. Filsafat Islam berbeda dengan fisasat barat yang berdasarkan kepentingan sendiri dan bersifat individualistik yang mengagungkan kebebasan individu dan mengutamakan kepemilikan individu, ataupun komunis yang mengutamakan kepemilikan pemerintah dan memberikan kekuasaan kepada pemerintah untuk menindas kepada rakyat (Ruziah, G. 2007). Oleh karena itu, Islam menetapkan peraturan yang jelas dan tegas untuk dilaksanakan sepanjang zaman kepada pemerintah untuk mengurus negara secara adil dan bijaksana untuk mencapai kesejahteraan rakyat. Salah satu peraturan Islam yang membolehkan pemerintah mendapat sumber dana bagi mengurus negara ialah pajak dan zakat.

Pajak merupakan sumber penerimaan Negara yang sangat penting dalam menopang pembiayaan pembangunan yang bersumber dari dalam negeri. Menurut Mangkoesoebroto (1998), pajak adalah:

"suatu pungutan yang merupakan hak prerogratif pemerintah, pungutan tersebut didasarkan pada undang-undang,pemungutannya dapat dipaksakan kepada subjek pajak untuk mana tidak ada balas jasa yang langsung dapat ditunjukkan penggunaannya."

Sedangkan definisi pajak menurut Undang-undang Nomor28 tahun 2007 tentang Ketentuan Umum Dan Tata Cara Perpajakan (UU KUP) adalah:

"kontribusi wajib kepada negara yang terutang oleh orang pribadi atau badan yang bersifat memaksa berdasarkan Undang-Undang, dengan tidak mendapatkan imbalan secara langsung dan digunakan untuk 
keperluan negara bagi sebesar-besarnya kemakmuran rakyat. Pajak dipungut penguasa berdasarkan norma-norma hukum untuk menutup biaya pengeluaran pemerintah untuk mencapai kesejahteraan umum".

Dari uraian di atas, pajak merupakan iuran yang dipaksakan oleh pemerintah kepada masyarakat, tanpa ada kompensasi langsung yang prinsip pemungutan pajak tersebut untuk menjaga kepentingan rakyat. Menurut Ruziah Ghazali (2007) dalam prinsip syariah Islam, pemerintah dengan rakyat bersama-sama bertanggungjawab. Pemerintah bertanggungjawab terhadap rakyat dan rakyat juga bertanggungjawab terhadap pemerintah. Sehingga prinsip utama pajak adalah kekuasan berada dikedua belah pihak, saling tolongmenolong karena pemerintah memberi pelayanan, dan memberikan fasilitas yang baik yang dibutuhkan oleh rakyat. Rakyat seharusnya memberikan kerjasama kepada pemerintah dengan mematuhi peraturan yang ditetapkan asal tidak menimbulkan kezaliman.

Zakat berbeda dengan pajak. Zakat adalah merupakan tanggungjawab agama. Zakat adalah salah satu rukun Islam yang ketiga. Zakat merupakan rukun yang amat ditekankan setelah syahadatain dan shalat. Barangsiapa mengingkari kewajiban berzakat, maka dia telah kafir dan diminta bertaubat. Namun, jika tidak akan dihukumi sebagai orang murtad dan dihukum bunuh. Adapun terhadap orangorang yang meyakini perihal kewajiban berzakat (hukum zakat itu wajib), akan tetapi enggan membayar atau menunaikan kewajiban tersebut lantaran bakhil dan kikir, maka zakatnya boleh diambil secara paksa oleh pihak pemerintah.

Zakat berarti tumbuh dan bertambah, juga bisa berarti berkah, bersih, suci, subur dan berkembang maju. Umat muslim telah diwajibkan oleh Allah SWT untuk mengeluarkan Zakat, seperti firman Allah SWT:

"Dan dirikanlah sholat dan tunaikanlah zakat dan taatlah kepada Rasul, supaya kamu diberi rahmat (Surat An Nur 24-56).

Selain itu, zakat bisa membantu para fakir dan miskin. Mereka adalah orang-orang yang tidak memiliki kecukupan nafkah. Karenanya, saudara-saudara mereka yang terbilang memiliki harta lebih, mengulurkan bantuan dan menutupi kebutuhan para fakir 
dan miskin. Allah SWT berfirman:

"Dan orang-orang yang dalam hartanya tersedia bagian tertentu, bagi orang (miskin) yang meminta dan orang yang tidak mempunyai apaapa (yang tidak mau meminta).-(Al-Maarij 24-25)

Itulah zakat yang disediakan bagi orang-orang tertentu yang mereka memiliki hak untuk memperolehnya. Dalam ayat lain, Allah Subhanahu wa Taala berfirman:

"Dan pada harta-harta mereka ada hak untuk orang miskin yang meminta dan orang miskin yang tidak mendapat bagian. (AdzDzariyat19)

Zakat merupakan salah satu rukun Islam dan wajib dikerjakan oleh orang Islam bagi yang cukup haulnya. Pajak Pendapatan adalah kewajipan yang dilaksanakan oleh pemerintah untuk orang yang layak dikenakan pajak. Kedua pembayaran tersebut dalam Islam dibayar kepada pemerintah. Zakat digunakan untuk membangunkan ekonomi Islam dan membantu orang fakir miskin untuk hidup sebagaimana umumnya. Pajak pendapatan pula digunakan untuk pembangunan negara seperti pembangunan infrastruktur dan lain-lain.

Berdasarkan pengertian di atas, dapat ditunjukkan perbedaan pajak dan zakat sebagaimana tabel 1 berikut ini.

Tabel: 1

\section{Perbedaan antara zakat dan pajak}

\begin{tabular}{ll}
\hline \multicolumn{1}{c}{ ZAKAT } & \multicolumn{1}{c}{ PAJAK } \\
\hline $\begin{array}{l}\text { Konsep Zakat adalah penyucian } \\
\text { jiwa dan harta (Yusuf Qardawi). } \\
\text { Tanggung Jawab agama/ibadah }\end{array}$ & $\begin{array}{l}\text { Konsep pajak adalah paksaan. } \\
\text { Dibebankan oleh pemerintah } \\
\text { kepada rakyat. }\end{array}$ \\
\hline Tidak membayar zakat berdosa & $\begin{array}{l}\text { Tidak membayar pajak dikenakan } \\
\text { denda oleh pemerintah. }\end{array}$ \\
\hline $\begin{array}{l}\text { Bayar zakat diwajibkan kepada } \\
\text { Muslim yang layak dan mampu } \\
\text { saja. }\end{array}$ & $\begin{array}{l}\text { Semua rakyat yang layak wajib } \\
\text { membayar pajak }\end{array}$ \\
\hline $\begin{array}{l}\text { Zakat dikumpulkan oleh } \\
\text { pemerintah dalam hukum Islam }\end{array}$ & $\begin{array}{l}\text { Pajak dikumpulkan oleh siapa } \\
\text { saja yang memerintah negara }\end{array}$ \\
\hline
\end{tabular}




\begin{tabular}{ll}
\hline $\begin{array}{l}\text { Sumber zakat bersumber dari } \\
\text { barang yang halal }\end{array}$ & $\begin{array}{l}\text { Sumber pajak dapat bersumber } \\
\text { dari apa saja, baik yang halal } \\
\text { maupun yang haram. }\end{array}$ \\
\hline $\begin{array}{l}\text { Tingkat zakat adalah tetap, yaitu } \\
85 \text { gram emas. Yang berubah } \\
\text { adalah nilai uangnya saja. }\end{array}$ & $\begin{array}{l}\text { Tingkat pajak dapat berubah- } \\
\text { ubah berdasarkan tingkat yang } \\
\text { ditetapkan oleh pemerintah pada } \\
\text { setiap tahun dan setiap tingkat } \\
\text { pendapatan. }\end{array}$ \\
\hline $\begin{array}{l}\text { Distribusi zakat berdarkan } \\
\text { ketentuan Al-Quran yaitu kepada } \\
8 \text { asnaf saja. Pemaknaan asnaf }\end{array}$ & $\begin{array}{l}\text { Distribusi pajak adalah untuk } \\
\text { membiayai semua aktifitas } \\
\text { pengeluaran pemerintah untuk }\end{array}$ \\
$\begin{array}{l}\text { yang berubah berdasarkan } \\
\text { perkembangan zaman. Menurut } \\
\text { Yusuf Qardawi, makna fisabilillah } \\
\text { bermaksud jihad, misalnya untuk } \\
\text { pembangunan pendidikan, masjid } \\
\text { dan jalan di jalan Allah. }\end{array}$ & \\
\hline
\end{tabular}

Sumber: Ghazali, Ruziah, (2007).

Dalam konteks Malaysia, pemerintah telah mencoba mengintegrasikan zakat dan pajak pendapatan dengan memberikan pengurangan pajak atas zakat yang telah dibayar oleh umat Islam, dan tidak terbatas. Seberapa besar pun zakat yang dibayar akan dikurangkan dari pajak yang seharusnya dibayarkan. Dengan syarat zakat dibayar pada tahun taksiran yang sama dan bukti/kwitansi adalah dari Jabatan/Majlis Agama Islam Negeri di Malaysia.

\section{Perkembangan Zakat di Malaysia}

Sistem Perundang-undangan Malaysia pasal 3(4) mengatakan bahwa agama Islam adalah terletak di bawah kuasa Sultan atau Raja bagi negara bagian yang memiliki raja dan di bawah Yang Di Pertuan Agong bagi negara bagian yang tidak memiliki Raja seperti Wilayah Persekutuan meliputi Kuala Lumpur, Labuan dan Putrajaya. Segala urusan administrasi dan pengelolaan berbagai jenis zakat di Malaysia adalah berada di bawah kuasa pemerintah negara bagian. Hal ini mengakibatkan undang-undang administrasi zakat berbeda disetiap negara bagian (Abd Halim Mohd Noor, et.al; 2005).. 


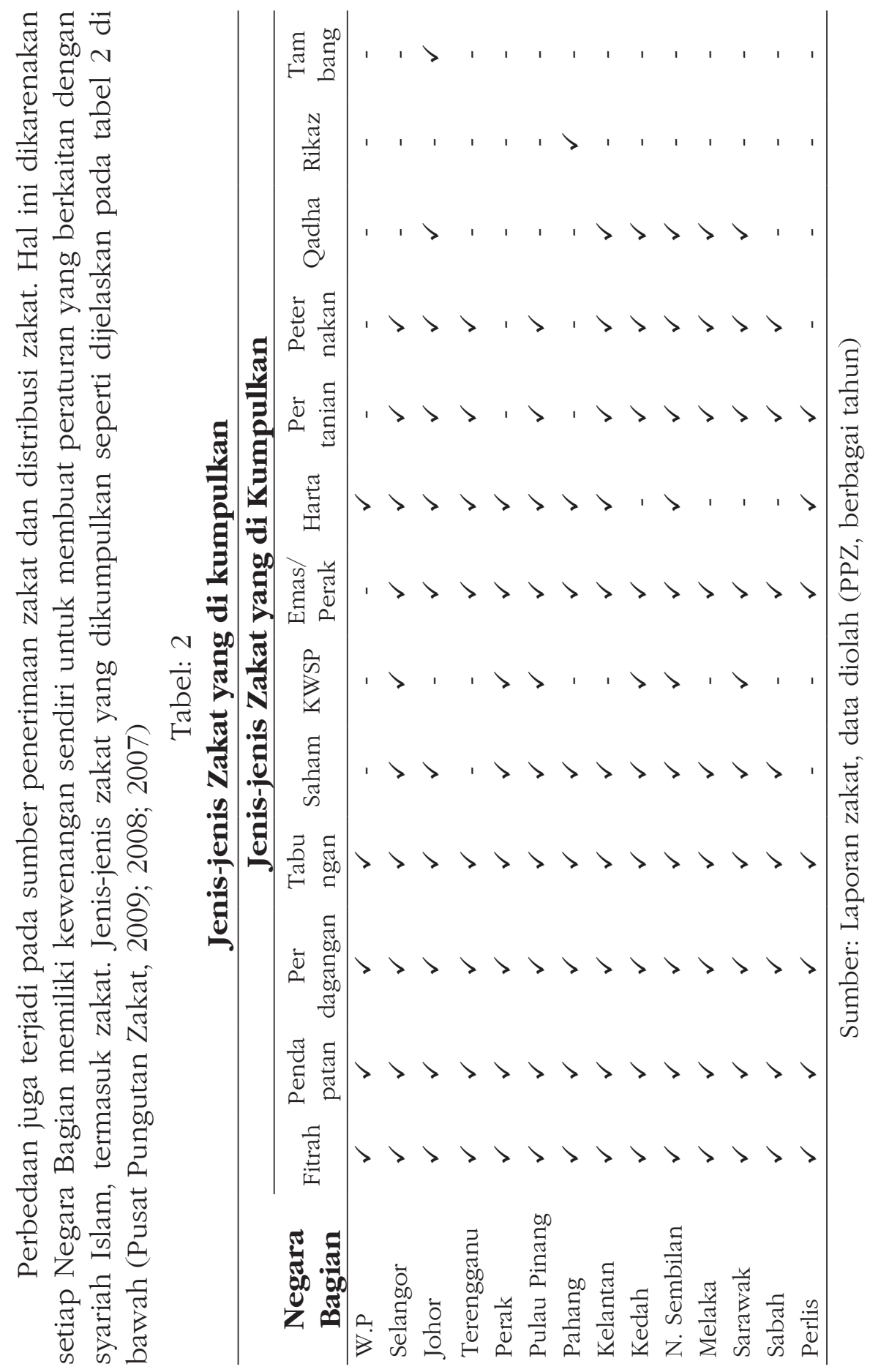


Selain itu, terdapat juga perbedaan mengenai distribusi kepada asnaf. Asnaf al-riqab hanya terdapat di Wilayah Persekutuan,Selangor dan Terengganu. Sedangkan Perlis dan Sabah tidak memasukkan asnaf al-gharimin dan al-riqab sebagai bagian dari penerima zakat. Pendistribusian zakat secara lengkap dapat dilihat pada tabel 3 di bawah (Pusat Pungutan Zakat, 2009; 2008; 2007).

Tabel: 3

\section{Distribusi Zakat kepada Asnaf}

\begin{tabular}{|c|c|c|c|c|c|c|c|c|}
\hline \multirow[b]{2}{*}{ Negeri } & \multicolumn{8}{|c|}{ Dsitribusi Zakat kepada Asnaf } \\
\hline & Fakir & Miskin & Amil & Mualaf & $\begin{array}{c}\text { Al- } \\
\text { Riqab }\end{array}$ & $\begin{array}{l}\text { Al-Gha- } \\
\text { rimin }\end{array}$ & $\begin{array}{l}\text { Ibnu } \\
\text { Sabil }\end{array}$ & $\begin{array}{c}\text { Fisabilil- } \\
\text { lah }\end{array}$ \\
\hline W.Persekutuan & $\checkmark$ & $\checkmark$ & $\checkmark$ & $\checkmark$ & $\checkmark$ & $\checkmark$ & $\checkmark$ & $\checkmark$ \\
\hline Selangor & $\checkmark$ & $\checkmark$ & $\checkmark$ & $\checkmark$ & $\checkmark$ & $\checkmark$ & $\checkmark$ & $\checkmark$ \\
\hline Johor & $\checkmark$ & $\checkmark$ & $\checkmark$ & $\checkmark$ & - & $\checkmark$ & $\checkmark$ & $\checkmark$ \\
\hline Terengganu & $\checkmark$ & $\checkmark$ & $\checkmark$ & $\checkmark$ & $\checkmark$ & $\checkmark$ & $\checkmark$ & $\checkmark$ \\
\hline Perak & $\checkmark$ & $\checkmark$ & $\checkmark$ & $\checkmark$ & - & $\checkmark$ & $\checkmark$ & $\checkmark$ \\
\hline Pulau Pinang & $\checkmark$ & $\checkmark$ & $\checkmark$ & $\checkmark$ & - & $\checkmark$ & $\checkmark$ & $\checkmark$ \\
\hline Pahang & $\checkmark$ & $\checkmark$ & $\checkmark$ & $\checkmark$ & - & $\checkmark$ & $\checkmark$ & $\checkmark$ \\
\hline Kelantan & $\checkmark$ & $\checkmark$ & $\checkmark$ & $\checkmark$ & - & $\checkmark$ & $\checkmark$ & $\checkmark$ \\
\hline Kedah & $\checkmark$ & $\checkmark$ & $\checkmark$ & $\checkmark$ & - & $\checkmark$ & $\checkmark$ & $\checkmark$ \\
\hline N. Sembilan & $\checkmark$ & $\checkmark$ & $\checkmark$ & $\checkmark$ & - & $\checkmark$ & $\checkmark$ & $\checkmark$ \\
\hline Melaka & $\checkmark$ & $\checkmark$ & $\checkmark$ & $\checkmark$ & - & $\checkmark$ & $\checkmark$ & $\checkmark$ \\
\hline Sarawak & $\checkmark$ & $\checkmark$ & $\checkmark$ & $\checkmark$ & - & $\checkmark$ & $\checkmark$ & $\checkmark$ \\
\hline Sabah & $\checkmark$ & $\checkmark$ & $\checkmark$ & $\checkmark$ & - & - & $\checkmark$ & $\checkmark$ \\
\hline Perlis & $\checkmark$ & $\checkmark$ & $\checkmark$ & $\checkmark$ & - & - & $\checkmark$ & $\checkmark$ \\
\hline
\end{tabular}

Sumber: Laporan Zakat, data diolah (PPZ, berbagai tahun)

Dalam perkembangan selanjutnya, pengelola zakat di setiap negara bagian mulai bertambah aktif dan inovatif. Berawal pada tahun 1991, di Majlis Agama Islam Wilayah Persekutuan (MAIWP) membuat terobosan dengan mendirikan Pusat Pungutan Zakat (PPZ) yang bertugas untuk mengumpulkan zakat di seluruh wilayah Persekutuan. PPZ dikenal sebagai amil, yang digaji dan bekerja secara profesional sebagai lembaga pengumpul zakat. Selanjutnya diikuti oleh Selangor melalui Pusat Zakat Selangor (MAIS) yang pada tahun 2006, ditingkatkan menjadi Lembaga Zakat Selangor (MAIS) diswastakan di bawah Akta Pemegang Amanah (Pemerbadanan) 1952. Dengan Selangor telah menswastakan lembaga zakatnya dengan membentuk Lembaga Zakat Selangor (LZS), selanjutnya 
diikuti oleh negara bagian yang lain (Abd Halim Mohd.Noor dan Azizan Dollah, 2006). Tabel 4. Menunjukkan status penswastaan lembaga zakat.

\section{Tabel: 4}

\section{Status Institusi Zakat di Malaysia}

\begin{tabular}{cl}
\hline No. & \multicolumn{1}{c}{ Pengelolaan Zakat yang di Swastakan } \\
\hline 1 & Pusat Pungutan Zakat Wilayah Persekutuan, MAIWP ${ }^{1}$ \\
2 & Lembaga Zakat Selangor, MAIS $^{2}$ \\
3 & ${\text { Pusat Urusan Zakat Pulau Pinang, MAIPP }{ }^{2}}^{2}$ \\
4 & ${\text { Pusat Pengumpulan Zakat Pahang, MAIP }{ }^{1}}_{5}$ Pusat Zakat Melaka, MAIM $^{1}$ \\
6 & Pusat Zakat Negeri Sembilan, MAINS $^{2}$ \\
\hline No. & \multicolumn{1}{c}{ Pengelolaan Zakat yang Tidak di Swastakan } \\
\hline 1 & Jabatan Zakat Negeri Kedah Darul Aman $^{2}$ \\
3 & Majlis Agama Islam Sarawak \\
4 & Majlis Agama Islam dan Adat Istiadat Melayu Terengganu \\
5 & Majlis Agama Islam dan Adat Istiadat Melayu Perlis \\
6 & Majlis Agama Islam Sabah dan Adat Istiadat Melayu Kelantan \\
7 & Majlis Agama Islam dan Adat Istiadat Melayu Perak \\
8 & Majlis Agama Islam Negeri Johor ${ }^{3}$ \\
\hline
\end{tabular}

Sumber: Abd Halim Mohd Noor dan Azizan Dolah, 2006.

1. Hanya unit pengumpulan yang diswastakan

2. Unit pengumpulan dan pendistribusian diswastakan

3. Dalam proses menswastakan institusi zakat.

Berbagai inovasi dan terobosan yang telah dibuat tersebut, memberikan pengaruh yang cukup besar terhadap hasil penerimaan zakat di Malaysia. Dimana setiap tahun, penerimaan zakat mengalami peningkatan yang cukup signifikan. Pada tahun 2008 total penerimaan zakatnya sebesar RM 1,038,092,894.24 atau setara Rp. 3,11 triliun atau meningkat sebesar 22\% dibandingkan penerimaan zakat pada tahun 2007 yang sebesar RM 806,284,071.53. 
Tabel: 5

\begin{tabular}{|c|c|c|c|}
\hline \multicolumn{4}{|c|}{$\begin{array}{l}\text { Penerimaan Zakat setiap negara bagian di Malaysia tahun } \\
\qquad 2007-2008 \text { (dalam RM) }\end{array}$} \\
\hline \multirow{2}{*}{ States } & \multicolumn{3}{|c|}{$\begin{array}{l}\text { Zakat Collection } \\
\end{array}$} \\
\hline & 2008 & 2007 & Perubahan \\
\hline W.P & $211,364,697.68$ & $173,815,154.35$ & $18 \%$ \\
\hline Selangor & $244,409,628.00$ & $202,193,541.00$ & $17 \%$ \\
\hline Johor & $100,737,539.79$ & $73,321,840.00$ & $27 \%$ \\
\hline Terengganu & $66,200,415.14$ & $51,442,341.96$ & $22 \%$ \\
\hline Perak & $56,962,446.06$ & $41,276,179.92$ & $28 \%$ \\
\hline Pulau Pinang & $41,764,273.00$ & $37,085,282.00$ & $11 \%$ \\
\hline Pahang & $57,935,146.89$ & $41,487,155.81$ & $28 \%$ \\
\hline Kelantan & $58,167,095.10$ & $40,199,886.62$ & $31 \%$ \\
\hline Kedah & $53,202,300.24$ & $36,692,723.92$ & $31 \%$ \\
\hline N. Sembilan & $37,409,710.68$ & $29,356,271.66$ & $22 \%$ \\
\hline Melaka & $26,905,934.29$ & $22,067,022.30$ & $18 \%$ \\
\hline Sarawak & $36,099,969.34$ & $23,132,088.56$ & $36 \%$ \\
\hline Sabah & $23,799,155.06$ & $17,514,982.50$ & $26 \%$ \\
\hline Perlis & $23,134,583.00$ & $16,699,600.00$ & $28 \%$ \\
\hline Total & $1,038,092,894.24$ & $806,284,071.53$ & $22 \%$ \\
\hline
\end{tabular}

Sumber: Pusat Pungutan Zakat WAIWP, (2009).

\section{Perkembangan Sistem Perpajakan di Malaysia}

Malaysia telah mengalami arus perubahan yang begitu cepat dan nyata di dalam sistem perpajakan negara dengan diperkenalkannya Sistem Taksiran Sendiri (Self Assessment). Bagi perseoran terbatas (PT) dan individu sistem ini dimulai pada tahun 2001, sedang usaha sendiri, CV dan Koperasi dimulai pada tahun 2004. Di dalam sistem ini, beban hutang perhitungan pembayaran pajak dialihkan kepada Pembayar Pajak dibandingkan sebelumnya yaitu atas beban Lembaga Hasil Dalam Negeri (LHDN atau kantor perpajakan). Dengan pelaksanaan sistem ini memberikan pengaruh terhadap perubahan pada masalah kepatuhan membayar dan denda keterlambatannya (Suhaila, Abdul Hamid. 2007).

Sistem taksiran sendiri adalah satu metode dimana pembayar pajak mengira serta membayar pajaknya sendiri. Hal itu bukan 
merupakan jenis pajak yang baru, tetapi satu sistem dimana pembayar pajak diberi tanggungjawab sepenuhnya untuk mengira, menghitung dan membayar pajaknya sendiri. Di dalam sistem taksiran sendiri, audit pajak dilakukan oleh LHDN merupakan alat pengawasan yang penting dalam memastikan bahwa pajak yang dilaporkan adalah benar dan sesuai dengan yang ditetapkan berdasarkan ketentuan yang berlaku. Audit Pajak ini akan memeriksa semua dokumen-dokumen pembayar pajak dan menjalankan tugas baik di LHDN ataupun di tempat pembayar pajak.

Setiap warganegara bertanggungjawab menjelaskan pajak pendapatan yang diperoleh baik di dalam atau di luar Malaysia. Sumber pendapatan yang dapat dikenakan pajak pendapatan diantaranya pendapatan dan keuntungan perdagangan, profesi dan gaji, insentif, pendapatan, dan keuntungan berdasarkan gaji, dividen, bunga atau diskon, sewa, royalti, pensiun, anuitas atau pembayaran berkala yang lain dan keuntungan yang berbentuk pendapatan yang tidak dinyatakan di atas. Pendapatan kena pajak diperoleh dari pendapatan dikurangi dengan semua bentuk biaya dan konsumsi dan kebutuhan lainya yang diakui oleh pemerintah yang dilakukan secara keseluruhan dalam usaha untuk mendapatkan pendapatan tersebut.

Kadar pajak tergantung kepada status individu penduduk tersebut, yang ditentukan oleh jangka masa tinggal di dalam negara ini (seperti yang dinyatakan dalam Akta Pajak Pendapatan 1967, di bawah Seksyen 7). Individu bermastautin atau penduduk tetap dikenakan pajak pendapatan dari $2 \%$ sampai 30\% setelah dikurangi dengan biaya pengurang pajak. Bagi individu dengan pendapatan kurang dari RM2,500 dibebankan pajak sebesar 0\%, dan 27\% untuk pendapatan lebih dari RM 250.000. Tingkat pajak secara rinci seperti disebutkan dalam tabel 6 di bawah. 
Tabel: 6

Tarif Pajak Penghasilan Individu di Malaysia Tahun 2009

\begin{tabular}{cclrr}
\hline Kategori & Tingkat Pendapatan (RM) & \multicolumn{1}{c}{ RM } & Tariff & Pajak (RM) \\
\hline A & $0-2,500$ & First 2,500 & 0 & 0 \\
B & $2,501-5,000$ & Next 2,500 & 1 & 25 \\
C & $5,001-10,000$ & First 5000 & & 25 \\
& & Next 5000 & 3 & 150 \\
D & $10,001-20,000$ & First 10,000 & & 175 \\
& & Next 10,000 & 3 & 300 \\
E & $20,001-35,000$ & First 20,000 & & 475 \\
& & Next 15,000 & 7 & 1,050 \\
F & $35,001-50,000$ & First 35,000 & & 1,525 \\
& & Next 15,000 & 12 & 1,800 \\
G & $50,001-70,000$ & First 50,000 & & 3,325 \\
& & Next 20,000 & 19 & 3,800 \\
H & $70,001-100,000$ & First 70,000 & & 7,175 \\
& & Next 30,000 & 24 & 7,200 \\
I & $100,001-150,000$ & First 100,000 & & 14,325 \\
& & Next 50,000 & 27 & 13,500 \\
J & $150,001-250,000$ & First 150,000 & & 27,825 \\
& & Next 100,000 & 27 & 27,000 \\
K & $>250,000$ & First 250,000 & & 54,825 \\
& & For every & 27 & \\
& & next ringgit & & \\
\hline
\end{tabular}

Sumber: www.hasil.gov.my diunduh pada tanggal 12 Juni 2010

\section{Zakat sebagai Pengurang Pajak}

Pemerintah Malaysia membuat kebijakan dengan memberikan pengurangan kepada pembayar zakat individu. Melalui model potongan pajak berjadwal atau sistem potongan bulanan (PCB) mereka akan menikmati pengurangan pajak sebesar dengan bayaran zakat atau zakat dapat digunakan untuk mengurangi pajak sampai dengan 100\% (Akta 53, 2. 6A (3). Tujuan dari langkah ini adalah sebagai salah satu cara menghindarkan pembayaran pajak berganda kepada hasil pendapatan para pembayar zakat tersebut (Ruzhiah Ghazali, 2007; Mahmood Zuhdi Haji Abd. Majid, 2007; Ahmad Mohammad Ibrahim, 1991, 648-649; Ahmad Mohammad Ibrahim, 1988; Abd. Rashid Dail, 1986). Secara tidak langsung juga ia akan 
memberikan insentif kepada masyarakat muslim untuk membayar zakat. Langkah tersebut merupakan satu tindakan yang berani karena sampai saat ini negara-negara Islam lain tidak memberikan insentif yang sama seperi yang dilakukan pemerintah Malaysia (Pusat Pungutan Zakat, 2001).

Dengan adanya insentif tersebut, ternyata memberikan implikasi yang signifikan terhadap penerimaan zakat di Malaysia. Pada tahun 2008, penerimaan zakat di seluruh negara bagian di Malaysia telah mencapai RM 1,2 milyar atau setara dengan Rp 3,36 triliun dengan jumlah penduduk + sebesar 28 juta orang dengan $60 \%$ penduduk beragama Islam (MAIWP; 2009). Ini sangat berbeda jauh jika dibandingkan dengan negara Indonesia dengan jumlah penduduk \pm 270 juta jiwa dengan 85\% beragama Islam.

Berdasarkan Akta Pajak Pendapatan 1967 mereka yang membayar zakat dikecualikan dari membayar pajak pendapatan mengikut besarnya zakat yang dibayar dan berlaku mulai tahun 1978. Hal ini dinyatakan dalam perkara 6A(1) akta berkenaan:

6A(1). Tertakluk kepada seksyen ini pajak pendapatan yang dikenakan bagi tahun taksiran atas pendapatan tiap-tiap orang individu yang bermastautin dalam tahun asas bagi tahun itu hendaklah direbetkan bagi tahun taksiran itu mengikut subseksyen (3). Rebet hendaklah diberi bagi tahun taksiran untuk zakat, fitrah atau lain-lain tuntutan agama Islam yang mana pembayarannya wajib dan telah dibayar dalam tahun asas bagi tahun taksiran itu dan dibuktikan oleh resit yang dikeluarkan oleh pihak berkuasa agama yang berkenaan yang ditubuhkan mengikut undang-undang bertulis.

\section{Metode Penelitian}

\section{Spesifikasi Model}

Artikel ini bertujuan untuk melihat pengaruh zakat terhadap penerimaan pajak di Malaysia. Untuk menyederhanakan koefisien persamaan, maka dalam artikel ini dibuat persamaan sebagai berikut:

$$
\ln T x_{i t}=b_{0}+b_{1} \ln Y_{i t}+b_{2} \ln Z_{i t}+\mu 1_{i t}
$$


di mana

$T=$ tahun

$i=$ Negeri di Semenanjung Malaysia $(1,2, \ldots \ldots \ldots . .11)$

$T x=$ Penerimaan Pajak Pemerintah Malaysia

$Y=$ Pendapatan domestik regional bruto (PDRB)

$Z=$ Penerimaan Zakat

\section{Definisi Operasional}

Model yang digunakan untuk menganalisis pengaruh zakat terhadap penerimaan pajak di Semenanjung Malaysia adalah model data panel. Menurut Hsiao (2003) dan Frei \& Campbell (2006) data panel memiliki dimensi masa dan ruang. Data panel adalah jenis data yang menggabungkan data runtut waktu dan data kerat lintang, sehingga penggunaannya memiliki kelebihan tersendiri yaitu dapat menyediakan informasi yang cukup kaya untuk mengembangkan teknik estimasi dan hasil teoretikal. Penggunaan data panel juga dimaksudkan untuk mengatasi keterbatasan data. Jika setiap unit kerat lintang memiliki jumlah observasi runtut waktu yang sama maka ini disebut sebagai balanced panel. Sebaliknya jika jumlah observasi runtut waktu berbeda untuk setiap unit kerat lintang maka ini disebut sebagai unbalanced panel. Penyelidikan ini memilih menggunakan data panel disebabkan beberapa kelebihan yang berikut; Lebih informatif, bervariasi, degree of freedom lebih besar dan lebih efisien,

1. Heterogenis bukan homogenis,

2. Lebih informatif, bervariasi, degree of freedom lebih besar dan lebih efisien,

3. Menghindari masalah multikolinearitas,

4. Lebih dapat mendeteksi dan mengukur pengaruh yang tidak dapat diobservasi pada data kerat lintang murni atau data runtut waktu murni,

Dalam analisa model data panel terdapat tiga pendekatan yang terdiri dari pendekatan kuadrat terkecil (pooled least square), pendekatan efek tetap (fixed effect), dan pendekatan efek random ( random effect). Untuk memudahkan pemahaman terhadap istilah 
dan variabel yang digunakan dalam penyelidikan ini perlu diberikan batasan operasional sebagai berikut:

a) Pajak (Tx) adalah total penerimaan pajak pemerintah. Data dalam bentuk ringgit (RM).

b) PDRB (Y) adalah pendapatan domestik regional bruto negara bagian di Semenanjung malaysia dalam bentuk Ringgit (RM).

c) Zakat $(Z)$ adalah penerimaan zakat di setiap negeri di Semenanjung Malaysia dalam bentuk Ringgit (RM). Data diperoleh dari MAIWP

\section{Data dan sumber data}

Penelitian ini meliputi 11 negeri atau negara bagian di Semenanjung Malaysia, yaitu Johor, Kedah, Kelantan, Melaka, Pahang, Negeri Sembilan, Perak, Perlis, Pulau Pinang, Selangor, Terengganu. Dengan periode pengamatan 2001 - 2009. Data diperoleh dari Jabatan Perangkaan Malaysia dan Rancangan-rancangan Malaysia, Economic Planning Unit Negeri dan Pusat dan Jabatan Audit Negara. Sedangkan data yang digunakan meliputi variabel dependent yaitu pengumpulan pajak, dan variable independent yang meliputi pengumpulan zakat, pertumbuhan ekonomi, dan total belanja pemerintah negara bagian.

\section{Analisi Regresi Data Panel}

Dalam penelitian ini digunakan data panel yaitu menggabungkan data lintas sektoral (cross section) dan data runtut waktu (time series) sehingga jumlah data meningkat. Keunggulan data panel antara lain (Baltagi; 1998); pertama memunculkan heterogenitas secara eskplisit ke dalam perhitungan dengan memasukkan variabel-variabel spesifik. Kedua, menyajikan data yang informatif, bervariase, kolinearitas antar variabel rendah, menambah jumlah derajat kebebasan dan lebih efisien. Ketiga, dengan masuknya obsevasi silang tempat, data panel dianjurkan studi perubahan dinamis. Keempat, lebih mampu mendeteksi dan mengukur efek dibandingkan dengan data silang tempat dan silang waktu murni. Kelima, menghasilkan model perilaku yang lebih kompleks. Keenam, meminimumkan bias pada data ketika 
dilakukan agregasi.

Penyatuan antara lintas waktu dan data runtut waktu akan menimbulkan masalah dalam proses estimasinya. Faktor pengganggu akan berpotensi mengandung gangguan yang disebabkan penggunaan data runtut waktu, data lintas sektoral serta gangguan karena penggabungan keduanya. Penggunaan data lintas sektoral mempunyai potensi tidak konsistennya parameter regresi, yang disebabkan karena skala data yang berbeda. Penggunaan data runtut waktu menimbulkan bahaya autokorelasi antar observasi.

Untuk mendapatkan estimasi-estimasi perkiraan yang akan di analisis, Pindyck dan Rubenfield mengatakan bahwa dalam ekonometri, ada 3 prosedur estimasi data panel guna mengatasi berbagai permasalahan penggabunagn kedua jenis observasi tersebut (Insukindro et.al, 2001), antara lain:

1. Penggabungan semua data runtut waktu dan data lintas sektoral, serta meregres dengan menggunakan metode OLS untuk seluruh set data.

2. Menghilangkan satu variable penjelas sehingga akan menyebabkan berubahnya intersep runtut waktu dan lintas sektoral,

3. Meningkatkan efisiensi estimasi parameter dengan cara mengatasi gangguan yang disebabkan karena penggunaan data runtut waktu dan data lintas sektoral. Oleh karena itu digunakan prosedur data panel yang disebut Error Component yang merupakan variasi dari proses estimasi generalized least-square (GLS).

\section{Analisis}

Sistem Perbitungan Zakat terhadap Pajak Pendapatan di Malaysia

Akta Pajak Pendapatan 1967, membolehkan semua individu Islam yang membayar zakat pendapatan dibolehkan mendapatkan pengurangan pajak pendapatan. Berbeda dengan perusahaan yang membayar zakat, mereka tidak dibolehkan membuat pengurangan dari jumlah pajak perusahaan. Sektor perusahaan hanya dibenarkan menggunakan pembayaran zakat untuk mengurangi pendapatan aggregat perusahaan dengan jumlah maksmimal RM50,000. 
Pada tahun 1978, pemerintah Malaysia mengesahkan aturan setiap pembayaran zakat individu dapat menjadi pengurang pajak. Pada tahun 1990, zakat pengurang pajak mulai diberikan kepada perusahaan yang membayar zakat dengan potongan sangat kecil. Jika pembayaran zakat individu dapat menjadi pemotongan pajak 100 persen, pada tahun 2005, pemerintah Malaysia mengeluarkan keputusan menerima zakat perusahaan menjadi pengurang pajak hanya sebesar 2.5 persen saja (Mohd, Shukor, 2007).

1. Akta Pajak Pendapatan

Pengurangan haruslah diberikan pada tahun taksiran untuk semua jenis pembayaran zakat, fitrah atau lain-lain kewajiban agama Islam yang merupakan pembayaran wajib, dan yang telah dibayar dalam tahun yang sama dengan tahun taksiran itu, dan dibuktikan oleh kwitansi yang dikeluarkan oleh pihak berkuasa agama yang bersangkutan yang didirikan berdasarkan undang-undang yang berlaku.

Tabel: 7

\section{Contoh 1 Perhitungan Pajak berdasarkan Akta Pajak Pendapatan}

Pajak Pendapatan Individu bagi tahun $\quad$ Rp 1.500.000 taksiran 2009

Zakat yang dibayarkan pada tahun 2009

Zakat Pendapatan

Rp 350.000

Zakat simpanan

Rp 100.000

Zakat Saham

Rp 200.000

Zakat Emas

Rp 50.000

Qadha Zakat yang dibayarkan

Rp 300.000

Jumlah zakat yang dibayarkan

Rp 1.000.000

\section{Jumlah pajak yang harus dibayarkan}

Rp 500.000

Berdasarkan contoh di atas, bahwa pajak yang masih harus dibayarkan oleh individu sebesar Rp 500.000,00. Dimana besarnya pajak yang masih harus dibayarkan adalah besarnya pajak yang harus dibayar dikurangi dengan pembayaran zakat oleh individu yang bersangkutan pada tahun yang sama. 
2. Akta Pajak Pendapatan 1967 Seksyen 6A(3)

Bayaran Zakat Dapat Digunakan sebagai Pengurang Pajak Pendapatan Individu

Berdasarkan kepada ACP 1967 di atas, setiap pembayaran zakat atas indirvidu baik itu zakat harta ataupun zakat fitrah mendapat rebet atau pengurangan dari pajak pendapatan seseorang. Pengurangan zakat hanya diperoleh jika pembayaran zakat dibuat pada tahun yang sama dengan taksiran pajak pendapatan.

Tabel: 8

\section{Contoh 2 Perhitungan Pajak Pendapatan}

\begin{tabular}{lc}
\hline $\begin{array}{l}\text { Pajak Pendapatan Individu bagi tahun } \\
\text { taksiran 2009 }\end{array}$ & Rp 1.500 .000 \\
Zakat yang dibayarkan pada tahun 2009 & \\
Zakat Pendapatan & Rp 450.000 \\
Zakat simpanan & Rp 300.000 \\
Zakat Saham & Rp 200.000 \\
Zakat Emas & Rp 100.000 \\
Qadha Zakat tahun 2008 & Rp 300.000 \\
Qadha zakat tahun 2007 & Rp 250.000 \\
Jumlah zakat yang dibayarkan & Rp 1.600 .000 \\
Jumlah pajak yang harus dibayarkan & Tidak ada \\
\hline
\end{tabular}

Sumber: Data terolah

Berdasarkan contoh 2 di atas, bahwa pajak yang masih harus dibayarkan oleh individu sebesar Rp 0, atau individu tersebut tidak berkewajiban membayar pajak. Hal ini dikarenakan besarnya zakat yang dibayarkan lebih besar dibandingkan dengan besarnya kewajiban membayar pajak pendapatan individu tersebut.

3. Potongan zakat di bawah Akta Pajak Pendapatan 1967 untuk Perusahaan/Badan.

a. Perusahaan Luar Pesisir Labuan

Pembayaran zakat yang disahkan sebagai pengurang pajak pendapatan di bawah Akta Pajak Perdagangan Luar Pesisir Labuat 1990 (LOBATA). 
Di bawah LOBATA, perusahaan memiliki 2 (dua) pilihan pembayaran yaitu:

1) Perusahaan dibebankan pajak sebesar $3 \%$ dari keuntungan bersih, atau

2) Perusahaan dapat memilih membayar pajak RM $20,000.00$ Bagi perusahaan di Luar Pesisir Labuan, zakat dapat digunakan sebagai pengurang pajak pendapatan sebesar zakat yang dibayarkan.

Misalkan:

PT. AZT sebuah perusahaan Luar Pesisir Labuan, memberikan laporan keuntungan bersih dari usaha Luar Pesisir Labuan pada tahun yang berakhir 31/12/2007 sebesar RM 1,000,000. Perusahaan tersebut membayar zakat pada tahun itu sebanyak RM 25,000.00

Perhitungan Pajak Pendapatannya untuk tahun 2007 adalah:

Keuntungan bersih

$$
\text { RM1,000,000 }
$$

Pajak dari 1,000,000 x 3\%

$$
=\mathrm{RM} 30,000
$$

Dikurangi : zakat

RM 25,000

Pajak yang harus di bayar

RM 5,000

Jika perusahaan memilih membayara pajak RM 20,000 maka perhitungannya adalah:

Pajak

$$
=\mathrm{RM} 20,000
$$

Dikurangi zakat RM 25,000

Pajak yang harus di bayar

NIHIL

b. Perusahaan

Pembayaran zakat yang disahkan sebagai pengurang pajak di bawah seksyen 44 (11A) ACP 1967. Berkuatkuasa mulai tahun taksiran 2005. Zakat digunakan sebagai pengurang pendapatan sebelum pajak, dan besarnya zakat adalah maksimum $2.5 \%$

Penyesuaian Bayaran Zakat Dengan Potongan Pajak Bulanan Pembayaran untuk semua jenis zakat dapat dikurangkan 
dari pajak pendapatan individu dengan syarat zakat dibayar sebelum 31 Desember setiap tahun dan dinyatakan dalam from return atau form pajak pendapatan. Setiap umat Islam yang telah membayar zakat boleh menuntut pengurangan ini dengan melampirkan kwitansi asli dan dikirim ke Lembaga Hasil Dalam Negeri dengan sistem Potongan Cukai Bulanan (PCB).

Contoh 1: PCB bagi Februari 2008

Zakat dibayar: RM55

PCB patut dipotong: RM95

PCB perlu dipotong: $\quad$ RM40 (RM95 - RM55)

Contoh 2: PCB bagi Mei 2008

Zakat dibayar: RM85

PCB patut dipotong: $\quad$ RM50

PCB perlu dipotong: TIADA

Kelebihan zakat RM35 (RM85 - RM50) dalam contoh 2 di atas dapat digunakan untuk mengurangi PCB pada bulan berikutnya. Tetapi, hanya berlaku pada tahun yang sama.

\section{Analisis Diskriptif: Penerimaan Zakat dan Pajak}

Perbandingan penerimaan zakat pendapatan dan pajak pendapatan

Akta Pajak Pendapatan 1967, membolehkan semua individu Islam yang membayar zakat pendapatan dibenarkan untuk mendapatkan pengurangan pajak pendapatan. Berbeda dengan perusahaan yang membayar zakat, mereka tidak dibolehkan melakukan pengurangan dari jumlah pajak perusahaan. Namun, sektor perusahaan hanya dibolehkan untuk melakukan pengurangan pembayaran zakat dari pendapatan aggregat perusahaan dan terbatas pada jumlah maksmimum RM50.000.

Tabel: 9

\section{Perbandingan Penerimaan Zakat Pendapatan Individu terhadap Penerimaan Pajak Pendapatan Individu Kerajaan}


Persekutuan

\begin{tabular}{cccc}
\hline \multirow{2}{*}{ Tahun } & \multicolumn{2}{c}{ Kerajaan Persekutuan } & \\
\cline { 2 - 3 } & Pajak (RM juta) & Zakat (RM Juta) & \\
\hline 2001 & $7.629,13$ & 148,84 & $1.95 \%$ \\
2002 & $6.095,16$ & 152,28 & $2.50 \%$ \\
2003 & $7.571,72$ & 191,56 & $2.53 \%$ \\
2004 & $9.470,66$ & 246,24 & $2.60 \%$ \\
2005 & $10.222,92$ & 281,13 & $2.75 \%$ \\
2006 & $10.409,65$ & 299,42 & $2.88 \%$ \\
2007 & $11.592,18$ & 368,63 & $3.18 \%$ \\
2008 & $14.346,52$ & 492,25 & $3.43 \%$ \\
\hline
\end{tabular}

Sumber: Lembaga Hasil dalam Negeri (berbagai Tahun, data diolah)

Laporan Zakat Tahunan (PPZ, berbagai tahun, data diolah)

Dari Tabel 9 di atas, menunjukkan perbandingan penerimaan zakat pendapatan dengan penerimaan pajak pendapatan Kerajaan Persekutuan. Hasil perbandingan menunjukkan bahwa dari tahun ke tahun terus mengalami kenaikan. Pada tahun 2001, jumlah penerimaan zakat pendapatan mencapai RM148,84 juta atau 1,95\% dibanding penerimaan pajak yang berjumlah RM7.629,13 juta. Pada tahun 2002 meningkat menjadi RM152,28 juta 2,50\% dibanding penerimaan pajak pada tahun 2002 yang berjumlah RM6,095.16. Walaupun jumlah penerimaan pajak mengalami penurunan, namun tidak berpengaruh kepada jumlah penerimaan zakat. Penerimaan zakat pada tahun 2002 mengalami kenaikan sebesar RM3,4 juta atau sebesar 2,31\% dibanding dari tahun 2001. Pada tahun 2007 dan 2008 perbandingannya sebesar 3,18\% dan 3,43\%. Ini bermakna bahawa penerimaan penerimaan zakat pendapatan telahpun melebihi besarnya zakat pendapatan iaitu 2,5\%. Hal ini bermakna bahawa kewajipan zakat telah menjadi hal yang semakin disedari oleh rakyat Malaysia.

\section{Perbandingan Penerimaan Zakat Harta dan Penerimaan Pajak Harta}

Penerimaan zakat dari tahun ke tahun mengalami peningkatan 
yang cukup tinggi. Hal ini kemungkinan disebabkan adanya langkah yang dilakukan oleh pemerintah Malaysia dengan memberikan insentif pengurangan pajak dengan pembayaran zakat. Sehingga memberikan insentif dan dorongan kepada umat Islam untuk menunaikan kewajipan zakatnya. Dan peningkatan tersebut juga diikuti oleh peningkatan penerimaan pajak, baik pajak pendapatan maupun pajak kekayaan (harta). Sehingga ketakutan yang selama ini terjadi bahwa jika zakat digunakan untuk mengurangi pajak akan mengurangi penerimaan pajak tidak beralasan. Bahkan malah akan meningkatkan penerimaan pajak, terutama pajak perdagangan dan pajak badan. Karena dengan adanya insentif pengurangan pajak sebesar 2,5\% karena membayar zakat akan mempermudah pemerintah untuk mengontrol dan mengurangi penghindaran dan pengelakan pajak. Sebagaimana dapat dilihat pada tabel 10.

Tabel: 10

\begin{tabular}{cccc}
$\begin{array}{c}\text { Perbandingan Penerimaan Zakat Harta terhadap Penerimaan } \\
\text { Pajak Harta dan Pendapatan Negeri-negeri di Malaysia } \\
\text { tahun } 2008\end{array}$ \\
\hline \multirow{2}{*}{ Negeri } & \multicolumn{2}{c}{$2008(\mathrm{RM})$} \\
\cline { 2 - 3 } & \multicolumn{2}{c}{ Zakat Harta } & Pajak Harta \\
\hline Selangor & $55.324 .316,00$ & 226.080 .000 .00 & $24,47 \%$ \\
Wilayah & $39.986 .392,71$ & - & \\
Persekutuan & & & \\
Johor & $28.042 .775,57$ & 132.912 .000 .00 & $21,10 \%$ \\
Perak & $25.647 .811,98$ & 96.145 .000 .00 & $26,68 \%$ \\
Trenggganu & $17.012 .878,54$ & 27.216 .000 .00 & $62,51 \%$ \\
Negeri Sembilan & $10.471 .031,96$ & 60.384 .000 .00 & $17,34 \%$ \\
Kelantan & $10.461 .337,63$ & 28.608 .000 .00 & $36,57 \%$ \\
Pulau Pinang & $9.056 .627,00$ & 60.336 .000 .00 & $15,01 \%$ \\
Pahang & $8.373 .591,36$ & 40.404 .000 .00 & $20,72 \%$ \\
Kedah & $7.286 .435,64$ & 94.530 .000 .00 & $7,71 \%$ \\
Melaka & $6.494 .686,72$ & 40.278 .000 .00 & $16,12 \%$ \\
Perlis & $1.900 .095,00$ & - & \\
Jumlah & $\mathbf{2 2 5 . 4 5 9 . 7 9 3 , 0 0}$ & $\mathbf{8 0 6 . 8 9 3 . 0 0 0 , 0 0}$ & $27,04 \%$ \\
\hline
\end{tabular}

Sumber: Lembaga Hasil Dalam Negeri (berbagai Tahun, data diolah), 
Laporan Zakat Tahunan (PPZ, berbagai tahun, data diolah) Wilayah Persekutuan, dan Perlis Laporan Pajak tidak diperoleh.

Pada tabel 10 di atas, terlihat bahwa perbandingan penerimaan zakat harta dengan penerimaan pajak harta di Semenanjung Malaysia memiliki rata-rata 27,04\% pada tahun 2008. Perbandingan penerimaan zakat harta terhadap jumlah penerimaan pajak harta terbesar ialah Negeri Terengganu dengan penerimaan zakat harta yang mencapai RM17.012.878,54 atau 62,51\% dibanding penerimaan pajak harta pada tahun 2008. Diikuti oleh Kelantan dengan jumlah penerimaan zakat harta mencapai RM10.461.337,63 atau 36,57\% dibanding jumlah penerimaan pajak harta pada tahun 2008 yang mencapai RM28.608.000,00. Sedangkan untuk perbandingan jumlah penerimaan harta dibanding jumlah penerimaan pajak harta terendah adalah Negeri Kedah iaitu sebesar 7,71\% pada tahun tahun 2008.

\section{Analisis Data}

Pengujian Ekonometrik Model dengan Hausman Test

Hausman Test digunakan untuk membantu menentukan pendekatan mana yang lebih cocok digunakan untuk menganalisis data panel, apakah pendekatan fixed effect atau random effect. Pengujian dilakukan dengan menguji hipótesis yang menyatakan bahwa random effect model lebih tepat digunakan dibandingkan dengan fixed effect model. Apabila nilai probabilitas ( $P$-Value) lebih besar atau sama dengan tingkat kesalahan (5\%), maka digunakan pendekatan random effect. Sebaliknya apabila nilai probabilitasnya siginifikan atau lebih kecil dari 0,05 (5\%), digunakan pendekatan fixed effect. Hasil pengolahan data untuk Hausman Test terlihat pada tabel 11 di bawah ini.

Tabel: 11

\section{Hausman Test}

$\begin{array}{cccc}\text { Test Summary } & \text { Chi-Sq. Statistic } & \text { Chi-Sq. d.f } & \text { Prob. } \\ \begin{array}{c}\text { Corss-section } \\ \text { random }\end{array} & 126.82 & 2 & 0.00\end{array}$


Sumber: Data terolah

Hasil analisis dalam tabel 11 menunjukkan bahwa nilai ChiSquare Statistic sebesar 126,82 dengan derajat kebebasan (degree of freedom) sebesar 2 dan nilai probabilitasnya ( $P$-Value) adalah 0,00. Nilai probabilitas 0,00 lebih kecil dari tingkat kesalahan yang digunakan dalam penelitian ini 0,05 (5\%), sehingga dapat disimpulkan bahwa hipotesis yang menyatakan bahwa random effect model lebih tepat digunakan dibandingkan dengan fixed effect model ditolak dan sebaiknya digunakan pendekatan fixed effect model untuk mengolah data panel dalam permasalahan ini.

Selain dari itu, sesuai dengan Hausman Test maka metode estimasi analisis regresi data panel akan menggunakan pendekatan fixed effect-cross section model, sesuai dengan tujuan penelitian ini untuk mengetahui bagaimana pengaruh zakat terhadap penerimaan pajak di Semenanjung Malaysia. Dengan metode estimasi fixed effect-cross section SUR (Seemingly Unrelated Regression) model, diharapkan pada akhirnya akan diperoleh persamaan regresi data panel dengan koefisien slope yang konstan dan koefisien intersep yang berbeda untuk setiap negara bagian. Cross Section SUR digunakan karena metode ini mengestimasi sekaligus mengoreksi cross section heteroscedasticity dan autocorrelation.

Hasil Analisis Regresi Data Panel Pengaruh Zakat terhadap Penerimaan Pajak

Berdasarkan hasil estimasi regresi terhadap data yang ada, diperoleh ringkasan hasil analisis sebagai berikut:

Tabel: 12

Hasil Analisa regresi persamaan penerimaan pajak

\begin{tabular}{ccccc}
\hline Variable & Coefficient & Std. Error & t-Statistic & Prob. \\
\hline C & 12.33310 & 0.714995 & 17.24922 & 0.0000 \\
LOG(Y_?) & -0.044253 & 0.133989 & -4.330272 & 0.0000
\end{tabular}




\begin{tabular}{|c|c|c|c|c|}
\hline LOG(Z_?) & 0.367601 & 0.058101 & 6.326958 & 0.0000 \\
\hline \multicolumn{5}{|l|}{$\begin{array}{l}\text { Fixed Effects } \\
\text { (Cross) }\end{array}$} \\
\hline $\mathrm{JOHOR}-\mathrm{C}$ & 0.547395 & & & \\
\hline $\mathrm{KEDAH}-\mathrm{C}$ & 0.467694 & & & \\
\hline KELANTAN-C & -0.527691 & & & \\
\hline MELAKA-C & -0.203758 & & & \\
\hline NEGERI9-C & -0.156171 & & & \\
\hline PAHANG-C & 0.194539 & & & \\
\hline PERAK-C & 0.754388 & & & \\
\hline PERLIS-C & -1.598887 & & & \\
\hline PPINANG-C & -0.193218 & & & \\
\hline SELANGOR-C & -0.996755 & & & \\
\hline TERENGGANU--C & -0.979825 & & & \\
\hline
\end{tabular}

Sumber: Hasil Analisis, Data diolah

* signifikan pada $\alpha=1 \%$

Penerimaan zakat dalam hasil analisis di atas memiliki pengaruh yang positif dan signifikan pada $\alpha=1 \%$ artinya jika penerimaan zakat meningkat maka penerimaan pajak akan meningkat. Hal ini bermakna bahwa di Malaysia, dengan adanya kebijakan pengurangan pajak dengan adanya pembayaran zakat untuk mengurangi pembayaran pajak individu tidak akan mengurangi penerimaan pajak, namun malah akan meningkatkan penerimaan pajaknya. Hal ini juga terbukti bahwa penerimaan zakat rata-rata setiap negeri dibandingkan dengan penerimaan pajak pemerintah terus mengalami kenaikan dan diikuti juga oleh kenaikan dalam penerimaan pajak. Hal ini mengikis kekhawatiran berbagai kalangan yang mengatakan bahwa zakat akan menurunkan penerimaan pajak.

Hal ini kemungkinan berlaku karena pemerintah akan semakin mudah memantau dan mengawasi masyarakat untuk tidak melakukan penghindaran pajak karena telah difasilitasi oleh pemerintah melalui zakat sebagai pengurang pajak. Namun demikian pemerintah tidak perlu khawatir kalau penerimaan zakat ini akan berpengaruh pada penurunan penerimaan pajak yang selanjutnya berpengaruh kepada 
pengeluaran karena pengeluaran pemerintah juga akan terkurangi dengan distrubusi zakat, maknanya sebagian beban pemerintah akan terkurangi sebesar distribusi zakat ini.

Selain itu, penerimaan dan distribusi zakat akan memberikan pengaruh yang lebih besar berbanding distribusi pemerintah dalam bentuk pengeluaran, sebab pengeluaran pemerintah sebagian besar adalah pengeluaran rutin yaitu gaji, pengeluaran rutin lainnya, seperti tunjangan pegawai, belanja barang, pemeliharaan dan sebagainya dan sedikit bagian pengeluaran pemerintah untuk redistribusi kembali pendapatan kepada mereka yang memerlukan. Berbeda dengan zakat yang pembagiannya telah dipastikan hanya untuk mereka yang memerlukan iaitu 8 asnaf dan itu pula menjadi kewajiban dari pemerintah untuk membiayai melalui pengeluarannya, namun sampai saat ini pengeluaran pemerintah masih sedikit untuk 8 asnaf tersebut. Oleh itu, dengan distribusi zakat ini, bisa mengurangi beban pemerintah untuk membiayai 8 golongan tersebut.

Di samping itu, zakat juga akan meningkatkan investasi modal dalam industri dan perdagangan akibat dari faktor psikologis. Zakat yang didistribusikan untuk asnaf terutama fakir dan miskin akan meningkatkan konsumsi dan investasi. Dengan meningkatnya konsumsi, akan meningkatkan keuntungan perdagangan, dan akan meningkatkan penerimaan pajak. Begitu juga dengan zakat untuk investasi, akan meningkatkan penerimaan tenaga kerja, sehingga pendapatan meningkat, dengan begitu akan meningkatkan juga penerimaan pajak. Disamping adanya keridloan Allah, sehingga semakin banyak orang yang membayar zakat.

\section{Kesimpulan}

Pengelolaan zakat di Malaysia telah ada semenjak masuknya Islam ke tanah Melayu, dan terus berkembang sampai saat ini. Bahkan terjadi perbedaan dalam hal pengelolaan di setiap negeri, namun tidak mempengaruhi dan menurunkan keinginan masyarakat untuk membayar zakat. Hal ini juga dikarenakan pembayaran zakat dapat digunakan untuk mengurangi pembayaran pajak sampai dengan 100\%. Artinya masyarakat yang sudah membayar zakat sebesar pembayarn pajak, mereka tidak diwajibkan atau diharuskan 
membayar pajak. Sehingga tidak tidak terjadi double tax accounting.

Hal ini malahan akan semakin meningkatkan penerimaan pajak oleh pemerintah. Karena dengan adanya zakat sebagai pengurang Pajak, akan memberikan rangsangan dan insentif kepada masyarakat muslim untuk lebih jujur dan benar dalam melakukan pengisian sendiri beban pajaknya. Disamping itu juga untuk mengurangi beban ganda pembayaran zakat dan pajak oleh masyarakat. Hal ini dibuktikan dengan data yang ada dan hasil analisis menyatakan bahwa zakat akan berpengaruh positif dan signifikan dalam mempengaruhi penerimaan pajak pemerintah. Artinya, semakin tinggi zakat yang dikumpulkan, akan semakin tinggi pula penerimaan pajak pemerintah. Sehingga kekhawatiran zakat akan menurunkan penerimaan pajak tidak beralasan.

\section{Daftar Pustaka}

Abd Halim Mohd. Noor, et.a. 2005, "Prestasi Pengagihan Dana Zakat di Malaysia", dalam Isu-isu Kontemporari Zakat di Malaysia, Jilid Satu; Menerajui Kecemerlangan Zakat, Abd. Halim Mohd Noor. et.al. edtr. Institut Kajian Zakat Malaysia (IkaZ), Universiti Teknologi MARA.

Ahmad Mohamed Ibrahim dan Ahilemah Joned. 1986, Sistem Undang-undang di Malaysia, Kuala Lumpur: Dewan Bahasa dan Pustaka, hal. 173.

Ahmad Mohamed Ibrahim. 1995, Mendekati Sejarah Undangundang di Malaysia dan Singapura, Kuala Lumpur: Dewan Bahasa dan Pustaka, hal. 16-18, 75-78, 124-125

Ahmad Mohamed Ibrahim. 1991, Pentadbiran Undang-undang Islam di Malaysia, Kuala Lumpur: Institut Kefahaman Islam Malaysia, hal. 648-649;

Baltagi, Badi H. 2008. Econometric Analysis of Panel Data, John Wiley and Sons, Chichester, 4th edition.

Frei, F.X., \& Campbell, D. 2006. Introduction to Panel Data, Boston: Harvard Business School.

Hsiao, C. 2003. Analysis of Panel Data, London: Cambridge University Press.

Insukindro, Maryatmo dan Aliman. 2001. Ekonometrika Dasar dan 
Penyusunan Indikator Ekonomi Unggulan, Modul Lokakarya Ekonometrika dalam Rangka Penjajakan Leading Indikator Export di KTI, Hotel Sedona, Makasar

Jabatan Audit Negara. 2010. Laporan Ketua Audit Negara tabun 2010. Kuala Lumpur.

Mangkoesoebroto, Guritno. 1998. Ekonomi Publik, Edisi kedua. BPFE - UGM, Yogyakarta.

Suhaila Abdul Hamid. 2007. The Zakat and Tax Practices for Individuals In Malaysia. Dalam Nik Salida Suhaila Nik Saleh, et. Al. ed, The Development of Economics and Muamalat Practices. In Conjunction with the Renaming of KUIM to USIM, Bandar Baru Nilai. Negeri Sembilan Darul Khusus.

Makalah dan Sumber dari Internet

Abd. Halim Mohd Noor dan Azizan Dolah. 2006. "Profesionalisasi/

Pengperusahaanan Institusi Zakat Ke Arah Peningkatan Pengelolaan dan Tadbir Urus Zakat Yang Terbaik". Makalah dipresentasikan dalam Konferensi Zakat Asia Tenggara: Membangun Peradaban dan Syi'ar Zakat Di Asia Tenggara. 30 Oktober s/d 3 November 2007, Padang Sumatera Barat.

Abd. Rashid Dail, 1986, "Zakat dan Cukai Pendapatan Mengikut Kacamata Islam”, Seminar Zakat dan Cukai Pendapatan di Malaysia, Kuala Lumpur, 5 Mei 1986

Ahmad Mohamed Ibrahim. 1988. "Penyelarasan Zakat Perniagaan, Penggajian dan Pendapatan Bebas", Seminar Penyelarasan Zakat dan Cukai Pendapatan di Malaysia, Kuala Lumpur, 28-29 Mac 1988;

Lembaga Hasil Dalam Negeri, www.hasil.gov.my

Mahmood Zuhdi Haji Abd. Majid. 2007. "Pemantapan Sistem Zakat dan Cukai ke Arah Kemajuan Ummah" paper dipresentasikan dalam Konveksyen Zakat dan Cukai Peringkat Kebangsaan 2007, Kuala Lumpur.

Mohd. Shukor. 2007. Layanan Bayaran Zakat Mengikut Peruntukan Akta Cukai Pendapatan 1967. Kertas kerja dibentangkan dalam Konvensyen Zakat dan Cukai Peringkat Kebangsaan 2007 di PWTC, Kuala Lumpur.

Park, H.M. (2008). Linear Regression Models for Panel Data Using 
SAS, STATA,LIMDEP and SPSS, diunduh dari http://www. indiana.edu/-statmath

Pusat Pungutan Zakat MAIWP. 2001. Laporan Zakat Tahunan 2010, Malaysia, diunduh dari www.zakat.com.my/buku-laporantahunan-ppz

Pusat Pungutan Zakat MAIWP. 2007. Laporan Zakat Tabunan 2007, Pusat Pungutan Zakat Wilayah Persekutuan, Kuala Lumpur Malaysia. www.zakat.com.my/buku-laporan-tahunan-ppz

Pusat Pungutan Zakat MAIWP. 2008. Laporan Zakat Tahunan 2008, Pusat Pungutan Zakat Wilayah Persekutuan, Kuala Lumpur Malaysia. www.zakat.com.my/buku-laporan-tahunan-ppz

Pusat Pungutan Zakat MAIWP. 2009. Laporan Zakat Tahunan 2009, Pusat Pungutan Zakat Wilayah Persekutuan, Kuala Lumpur Malaysia. www.zakat.com.my/buku-laporan-tahunan-ppz

Ruziah Ghazali. 2007. "Implikasi Zakat terhadap Sistem Percukaian Negara”, paper dipresentasikan dalam Konveksyen Zakat dan Cukai Peringkat Kebangsaan, Kuala Lumpur. 